\title{
An Empirical Study on the Impacts of Organizational Innovation on Performance of Nonprofit Organizations Based on QCA
}

\author{
Yanbing Zhang, Yuanqing Cai \\ Tsinghua University, Beijing, China
}

\begin{abstract}
Organizational innovation is particularly important as the soft power of nonprofit organization. This paper discloses that the improvement of performance of nonprofit organizations depends on the combination of different elements of organizational innovation instead of the strength of an element in organizational innovation; and the strength of organizational innovation elements in different nonprofit organizations varies. Based on 23 tertiary hospitals in Beijing, it employs qualitative comparative analysis (QCA) to make an empirical study of the impacts of organizational innovation on performance of nonprofit organizations. The study proves that the main factors to promote performance of nonprofit organizations are the combination of different elements of organizational innovation, including product innovation, process innovation, and management innovation. The optimal performance in nonprofit organizations for a collection of logic is: the introduction of new services or projects * organize new activities for customers, employees, or volunteers * the introduction of new service delivery + provide new training topics for employees or volunteers * adopt a new organizational structure * implement new recruitment of staff and volunteer.
\end{abstract}

Keywords: nonprofit organizations, organizational innovation, QCA

Innovation is becoming a key determinant of nonprofit organizations. Nonprofit organizations play an increasingly important role in providing social services, and multiple changes in the external environment are reengineering the survival rules of nonprofit organizations (Harris, 1989). Innovation is the source of the organization to maintain competitiveness. J. A. Schumpeter defines that innovation refers to the transfer of a production function, or a reorganization of production elements and production conditions to introduce a production system and change its technological system, in order to obtain entrepreneurial profits or potential excess profits. Schumpeter agrees that the power of the development of modern economy is not capital and labor, but the innovation, and innovation is the key to the production, dissemination, and use of knowledge and information.

\section{Literature on Innovation of Nonprofit Organizations}

After Schumpeter, the development of innovation theory has experienced the following two important stages: (1) from the 1950s to the mid-70s, on the basis of the innovation theory of Schumpeter, the research

Yanbing Zhang, Ph.D., associate professor, School of Public Policy \& Management, Tsinghua University, Beijing, China; research fields: politics, international political economics.

Corresponding author: Yuanqing Cai, Ph.D. candidate, School of Public Policy \& Management, Tsinghua University, Beijing, China; research fields: innovation management and public policy, public health policy and social network analysis. 
built the basic framework of technological innovation theory and the research category; (2) after the mid-1970s, the research of innovation theory developed in the direction of integration. On the basis of the new growth theory of "endogenous technology" and on the basis of the new institutional economics of "institutional determinism", the research greatly promotes the development of the theory of innovation.

The concept of organizational innovation has not been unified. The concept of organizational innovation is defined based on different research perspectives. Some scholars, from the perspective of organizational structure, pointed out that the organizational innovation is a systematic structure, including rearranged task, increase of jobs, and increase or decrease in the budget. Blau and Mckinley (1979) attributed organizational innovation to the following three points: (1) to recognize, improve, and implement new ideas including all members of the organization; (2) to generate new ideas; (3) to integrate several concepts or things to create process. Kimberly (1981) pointed out that the organizational innovation was the recognition and implementation of new processes, new products, or new functions. Bai and Zhang (2005) argued that organizational innovation was based on structure adjustment, combined with the organization system, members of the organization's values, and behavior patterns of mutual adjustment to ensure the business process reengineering. And scholars defined organizational innovation in the perspective of a process, including the absorption of new knowledge, the transition of the links, and the recycling of services and resources. West and Farr (1990) argued that organizational innovation was the organization's new approach to the introduction and application of ideas, products, and procedures for individuals, groups, or organizations in order to benefit individuals, groups, and society as a whole. Scott and Bruce (1994) argued that innovation was the result of the interaction of individuals, leaders, work teams, and organizational atmosphere, and the organizational atmosphere was an important manifestation of the culture of the firm, which represented the main content of the enterprise's informal system. Lumpkin and Dess (1996) highlighted that the results of organizational innovation would produce new products, services, or technology that reflected the organization's support for new concepts, experiments, and innovation processes. Faridah and Faïz (2001) argued that organizational innovation involved innovation in the stability of existing markets and the development of new markets for strategic innovation, $\mathrm{R}$ \& D capabilities and product performance, and management of good systems and corporate culture. Tidd and Hull (2003) argued that organizational innovation was a form of change in the use of a technology, a service, a product, or a new administrative activity. Chen, $\mathrm{He}$, and $\mathrm{Si}$ (2007) pointed out that organizational innovation was a process in which organizations continue to adapt to changes in the internal and external environment, effectively adapting the organization's capabilities and resources to improve the organizational performance of creative integration activities.

No one would be surprised to find that organizational innovation is a complex variable. From the perspective of the function of organizational innovation, technology innovation and institution innovation are the most important parts. Among them, the technology innovation can be divided into various types according to different ways, such as radical innovation, gradual innovation, process innovation, independent innovation, imitation innovation, etc. Researchers pay more attention to radical innovation and incremental innovation. Radical innovation brings customers new product features or performance attributed to the enterprise of new products and new technology, while gradual innovation increases additional value for customers. System innovation can be divided into two levels: (1) the macroeconomic system innovation: property right system, financial policy, industry regulation; (2) the microeconomic system innovation: incentive system, personnel system, production organization, and so on. 
According to the above research, this paper used an empirical study on the impacts of organizational innovation on performance of nonprofit organizations. From two aspects of technological innovation and management innovation, the authors explore what kind of attributes of nonprofit organization has a core and key role in non-profit organizations.

\section{Assignment of Conditional Variables}

This paper adopted scale (Jaskyte \& Dressler, 2005) of nonprofit organization innovation including a total of 13 items by reference to the Perri (1993) and Damanpour and Evan (1984) (see Table 1).

Table 1

Measuring Dimensions of Nonprofit Organization Innovation

\begin{tabular}{l} 
1. The introduction of new services or projects \\
2. Significant changes in existing services or projects \\
3. Extend the existing services to new customers \\
4. Produce some new products \\
5. Organize new activities for customers, employees, or volunteers \\
$\begin{array}{l}\text { 6. Redesign existing products } \\
\text { 7. Significant changes in the delivery of existing services } \\
\text { 8. The introduction of new service delivery } \\
\text { 9. Provide new training topics for employees or volunteers } \\
\text { 10. Adopt a new organizational structure } \\
\text { 11. Implement new recruitment of staff and volunteer } \\
\text { 12. Implement new incentives of employee and volunteer } \\
\text { 13. Implement new performance evaluation system }\end{array}$ \\
\hline Management innovation
\end{tabular}

According to the technological innovation and management innovation of nonprofit organizations, this paper sets out 13 conditional variables, namely: (1) the introduction of new services or projects; (2) significant changes in existing services or projects; (3) extend the existing services to new customers; (4) produce some new products; (5) organize new activities for customers, employees, or volunteers; (6) redesign existing products; (7) significant changes in the delivery of existing services; (8) the introduction of new service delivery; (9) provide new training topics for employees or volunteers; (10) adopt a new organizational structure; (11) implement new recruitment of staff and volunteer; (12) implement new incentives of employee and volunteer; and (13) implement new performance evaluation system.

The outcome variable of this paper is the performance of nonprofit organizations. In view of the multidimensional nature of the performance of nonprofit organizations, this study used the nonprofit 
performance measurement tools of six categories of customer performance and financial performance. Each dimension includes three items. In addition, many previous studies have shown that there is a strong correlation between subjective and objective performance indicators. Therefore, this research evaluates the performance of nonprofit organizations in a subjective way, using the Likert five-point scale. The appropriate number is used to indicate the degree of compliance according to the result of the comparison, where "1" means "completely nonconforming" and "5" means "fully compliant".

In this paper, Qualitative Comparative Analysis (QCA) is used to assign conditional variables. The method of QCA is pioneered by the sociologist Ragin, based on the principles of architecture theory and holistic theory, and can make effective causal explanations for the causes and results of multiple concurrency conditions. In recent years, with the development and maturity of this method, more and more Western scholars have applied QCA to the field of management. Domestic scholars also note that it is different from the unique value of general statistical methods, which has a combination of multiple concurrent conditions. The authors use QCA for the following considerations: Firstly, the impact of the independent variables on performance of nonprofit organizations or interaction between the conventional analysis is not enough. The authors need to consider a combination of conditions from the overall relationship. In this way, the authors will explore the conditional variables that cannot be separated from other factors. The authors do not pay attention to the net effect of the conditional variables on the result variables. The authors focus on the explanatory force of the result variables and the combination of condition variables. Secondly, the method of QCA allows better handling of the asymmetry of conditional variables, as compared to statistical methods that can only deal with perfectly symmetric (if $\mathrm{C} \rightarrow \mathrm{P}$, then $-\mathrm{C} \rightarrow-\mathrm{P}$ ). Even if $\mathrm{C} \rightarrow \mathrm{P}$ is established, then $-\mathrm{C} \rightarrow-\mathrm{P}$ is not necessarily established. Thirdly, the performance of nonprofit organization may have a variety of "equivalent" causal chain. Unlike the interpretation of the result variables by defining the regulatory effect and the mediating effect, the method of QCA does not just form an alternative or cumulative relationship, but rather an equivalent relationship. Fourthly, this study selected 23 cases in Beijing, including not only the representative individuals of Dongcheng District, Xicheng District, Xuanwu District, Chaoyang District, Shijingshan District, Haidian District, and Tongzhou District, but also accorded with the requirement of sample size of QCA.

Based on the above discussion, this paper chooses (fussy-set) qualitative comparison analysis (fsQCA). The basic idea is to set the social phenomenon to be defined as a relatively clear result variable. Its potential influencing factors are transformed into a number of two categories of explanatory variables through professional software to generate a combination as the basis for analysis. The variable has a value of 1 for a condition that occurs or exists. A variable of 0 indicates that a condition does not occur or does not exist. The relationship between variables is represented by a mathematical symbol (“*” means "and", "+” means "or", “=” or the arrow indicates "cause", such as $\mathrm{A} * \mathrm{~B} \rightarrow \mathrm{Y}$, means the occurrence of $\mathrm{Y}$ ). Using the method of "calibration", the data is converted to binary variables of the Boolean value. Among them, by analyzing the "technological innovation" and "management innovation" of nonprofit organizations, the authors analyzed what kind of attributes have a more central and more critical effect on the performance of nonprofit organizations and studied the impact of key variables on performance of nonprofit organizations. It should be noted that the performance of the nonprofit organization is 1 in this paper, indicating that the performance of nonprofit organization is high; the performance of the nonprofit is 0 in this paper, indicating that the performance of nonprofit organization is low. 


\section{Data Collection and Analytical Methods}

In this paper, the method of random stratified sampling was used to study the 23 tertiary hospitals in Dongcheng District, Xicheng District, Xuanwu District, Chaoyang District, Shijingshan District, Haidian District, and Tongzhou District. The questionnaire consists of three parts. The first part is the non-profit organization innovation scale survey of innovation ability in Beijing public hospital; the second part is organizational performance in Beijing public hospital; and the third part is the background information of the respondents. The appropriate number is used to indicate the degree of compliance according to the result of the comparison, where " 1 " means "completely disagree" and "5" means "fully agree" (see Table 2).

Table 2

Investigation Table

\begin{tabular}{|c|c|c|c|c|c|c|c|}
\hline Classification & index & Physician & Nurse & Technician & Manager & Total & Effective percentage \\
\hline \multirow[b]{2}{*}{ Gender } & Male & 86 & 4 & 25 & 16 & 131 & $37.2 \%$ \\
\hline & & 58 & 81 & 53 & 29 & 221 & $62.8 \%$ \\
\hline \multirow{3}{*}{ Education } & Master or above & 123 & 14 & 32 & 8 & 177 & $50.3 \%$ \\
\hline & Undergraduate & 21 & 59 & 37 & 21 & 138 & $39.2 \%$ \\
\hline & College and below & 0 & 12 & 9 & 16 & 37 & $10.5 \%$ \\
\hline \multirow{4}{*}{ Title } & Primary title & 18 & 33 & 16 & 8 & 75 & $21.3 \%$ \\
\hline & Intermediate title & 39 & 32 & 34 & 22 & 127 & $36.1 \%$ \\
\hline & Senior title & 82 & 12 & 21 & 9 & 124 & $35.2 \%$ \\
\hline & Without title & 5 & 8 & 7 & 6 & 26 & $7.4 \%$ \\
\hline \multirow{5}{*}{$\begin{array}{l}\text { Working time } \\
\text { in hospital }\end{array}$} & $1-5$ years & 37 & 26 & 15 & 14 & 92 & $26.1 \%$ \\
\hline & $6-15$ years & 48 & 27 & 25 & 7 & 107 & $30.4 \%$ \\
\hline & $16-25$ years & 42 & 17 & 21 & 7 & 87 & $24.7 \%$ \\
\hline & $26-35$ years & 17 & 15 & 15 & 17 & 64 & $18.2 \%$ \\
\hline & Above 36 years & 0 & 0 & 2 & 0 & 2 & $0.6 \%$ \\
\hline
\end{tabular}

The nonprofit organization innovation scale measures the innovation of nonprofit organization from three aspects: technological product innovation, technological process innovation, and management innovation. The correlation coefficient between the 13 dimensions of the nonprofit organization innovation scale has been shown in Table 3. 
Table 3

Correlation Coefficient Table

\begin{tabular}{|c|c|c|c|c|c|c|c|c|c|c|c|c|c|c|c|}
\hline & Mean & SD & 1 & 2 & 3 & 4 & 5 & 6 & 7 & 8 & 9 & 10 & 11 & 12 & 13 \\
\hline 1 & 4.09 & 0.834 & 1.000 & & & & & & & & & & & & \\
\hline 2 & 3.85 & 0.880 & $0.158^{* *}$ & 1.000 & & & & & & & & & & & \\
\hline 3 & 3.76 & 0.949 & 0.084 & $0.461^{* *}$ & 1.000 & & & & & & & & & & \\
\hline 4 & 4.19 & 0.780 & 0.097 & $0.548^{* *}$ & $0.403^{* *}$ & 1.000 & & & & & & & & & \\
\hline 5 & 4.15 & 0.796 & $0.131^{*}$ & $0.508^{* *}$ & $0.379^{* *}$ & $0.777^{* *}$ & 1.000 & & & & & & & & \\
\hline 6 & 4.10 & 0.831 & 0.094 & $0.555^{* *}$ & $0.392^{* *}$ & $0.687^{* *}$ & $0.744^{* *}$ & 1.000 & & & & & & & \\
\hline 7 & 4.12 & 0.857 & 0.104 & $0.648^{* *}$ & $0.506^{* *}$ & $0.609^{* *}$ & $0.550^{* *}$ & $0.599^{* *}$ & 1.000 & & & & & & \\
\hline 8 & 4.22 & 0.849 & $0.141^{* *}$ & $0.588^{* *}$ & $0.406^{* *}$ & $0.583^{* *}$ & $0.572^{* *}$ & $0.610^{* *}$ & $0.688^{* *}$ & 1.000 & & & & & \\
\hline 9 & 4.34 & 0.730 & $0.180^{* *}$ & $0.521^{* *}$ & $0.377^{* *}$ & $0.573^{* *}$ & $0.585^{* *}$ & $0.548^{* *}$ & $0.653^{* *}$ & $0.729^{* *}$ & 1.000 & & & & \\
\hline 10 & 4.07 & 0.877 & $0.151^{* *}$ & $0.639^{* *}$ & $0.477^{* *}$ & $0.579^{* *}$ & $0.523^{* *}$ & $0.595^{* *}$ & $0.716^{* *}$ & $0.682^{* *}$ & $0.668^{* *}$ & 1.000 & & & \\
\hline 11 & 4.17 & 0.788 & $0.111^{*}$ & $0.605^{* *}$ & $0.421^{* *}$ & $0.588^{* *}$ & $0.560^{* *}$ & $0.578^{* *}$ & $0.657^{* *}$ & $0.642^{* *}$ & $0.622^{* *}$ & $0.745^{* *}$ & 1.000 & & \\
\hline 12 & 4.21 & 0.758 & $0.115^{*}$ & $0.539^{* *}$ & $0.497^{* *}$ & $0.512^{* *}$ & $0.525^{* *}$ & $0.559^{* *}$ & $0.610^{* *}$ & $0.584^{* *}$ & $0.551^{* *}$ & $0.679^{* *}$ & $0.775^{* *}$ & 1.000 & \\
\hline 13 & 3.98 & 0.847 & 0.071 & $0.653^{* *}$ & $0.412^{* *}$ & $0.558^{* *}$ & $0.525^{* *}$ & $0.606^{* *}$ & $0.695^{* *}$ & $0.633^{* *}$ & $0.607^{* *}$ & $0.708^{* *}$ & $0.689^{* *}$ & $0.659^{* *}$ & 1.000 \\
\hline
\end{tabular}

Note. ${ }^{* *}$ means $p<0.01,{ }^{*}$ means $p<0.05$, both are two-tailed test; $\mathrm{N}=352$.

The nonprofit organization innovation scale uses the internal consistency test (Cronbach's alpha coefficient $\alpha$ ), which has a reliability coefficient of 0.918 , indicating that the nonprofit organization innovation scale has a good measure of reliability. The results of the internal consistency show that the internal consistency of the 13 dimensions of the nonprofit innovation scale is higher than 0.8 , which is higher than the recommended value of the reliability factor $(0.7)$ (see Table 4 ).

Table 4

Internal Consistency Coefficient Table

\begin{tabular}{llllllllllllll}
\hline & 1 & 2 & 3 & 4 & 5 & 6 & 7 & 8 & 9 & 10 & 11 & 12 & 13 \\
\hline$\alpha$ coefficient & 0.883 & 0.859 & 0.867 & 0.859 & 0.860 & 0.858 & 0.855 & 0.856 & 0.860 & 0.854 & 0.858 & 0.924 & 0.857 \\
\hline
\end{tabular}

The results of the single factor model, the two-factor model, and the three-factor model were compared by the analysis of AMOS 22.0. The results show that the scale has good structural validity: $\chi^{2} / d f=4.786$, GFI $=0.878, \mathrm{NFI}=0.909, \mathrm{IFI}=0.927, \mathrm{TLI}=0.907, \mathrm{CFI}=0.926$, and $\mathrm{RMSEA}=0.104$. The results show that the three-factor model is basic fitting level, so the structural validity of the nonprofit innovation scale has been effectively verified (see Table 5). 
Table 5

Confirmatory Factor Analysis Results

\begin{tabular}{lccccccccc}
\hline Model & $\chi^{2}$ & $d f$ & $\chi^{2} / d f$ & $G F I$ & NFI & IFI & TLI & CFI & RMSEA \\
\hline Single factor model & 415.903 & 65 & 6.399 & 0.838 & 0.873 & 0.890 & 0.868 & 0.890 & 0.124 \\
Two-factor model & 367.555 & 64 & 5.743 & 0.852 & 0.887 & 0.905 & 0.884 & 0.905 & 0.116 \\
Three-factor model & 296.753 & 62 & 4.786 & 0.878 & 0.909 & 0.927 & 0.907 & 0.926 & 0.104 \\
\hline
\end{tabular}

\section{Organizational Innovation Influences the Performance of Nonprofit Organizations}

The paper used 23 cases of public hospitals with two methods of QCA (qualitative comparative analysis) and regression analysis. QCA can better analyze the effect of condition combination on nonprofit organizations, while regression is based on the concept of independent variables between different variables. The analysis of organizational performance in nonprofit organizations needs to include both the mechanism and the factors. Therefore, based on the use of QCA and regression analysis, this paper analyzes the factors and mechanisms that affect the performance of nonprofit organizations in the country.

\section{Based on the Use of Qualitative Comparison Analysis}

The paper selects "the introduction of new services or projects", "significant changes in existing services or projects", "extend the existing services to new customers", "produce some new products", "organize new activities for customers, employees, or volunteers", "redesign existing products", "significant changes in the delivery of existing services", and "the introduction of new service delivery" as eight explained variables to explain the outcome variable and establishes truth table A of technological innovation in nonprofit organizations, as shown in Table 6.

Table 6

Truth Table A

\begin{tabular}{|c|c|c|c|c|c|c|c|c|c|}
\hline $\begin{array}{l}\text { The } \\
\text { introduction } \\
\text { of new } \\
\text { services or } \\
\text { projects }\end{array}$ & $\begin{array}{l}\text { Significant } \\
\text { changes in } \\
\text { existing } \\
\text { services or } \\
\text { projects }\end{array}$ & $\begin{array}{l}\text { Extend the } \\
\text { existing } \\
\text { services to } \\
\text { new } \\
\text { customers }\end{array}$ & $\begin{array}{l}\text { Produce } \\
\text { some new } \\
\text { products }\end{array}$ & $\begin{array}{l}\text { Organize new } \\
\text { activities for } \\
\text { customers, } \\
\text { employees, or } \\
\text { volunteers }\end{array}$ & $\begin{array}{l}\text { Redesign } \\
\text { existing } \\
\text { products }\end{array}$ & $\begin{array}{l}\text { Significant } \\
\text { changes in the } \\
\text { delivery of } \\
\text { existing } \\
\text { services } \\
\end{array}$ & $\begin{array}{l}\text { The } \\
\text { introduction } \\
\text { of new } \\
\text { service } \\
\text { delivery } \\
\end{array}$ & Case & $\begin{array}{l}\text { Organizational } \\
\text { performance }\end{array}$ \\
\hline 1 & 1 & 1 & 1 & 1 & 1 & 1 & 1 & 4 & 1 \\
\hline 1 & 0 & 1 & 1 & 1 & 1 & 1 & 1 & 3 & 1 \\
\hline 0 & 1 & 0 & 0 & 1 & 1 & 0 & 0 & 1 & 1 \\
\hline 0 & 0 & 0 & 0 & 1 & 0 & 0 & 1 & 1 & 1 \\
\hline 0 & 0 & 0 & 0 & 1 & 1 & 0 & 1 & 1 & 1 \\
\hline 0 & 1 & 1 & 1 & 1 & 1 & 1 & 1 & 1 & 1 \\
\hline 0 & 0 & 1 & 1 & 1 & 1 & 0 & 1 & 2 & 0 \\
\hline 0 & 0 & 0 & 0 & 0 & 0 & 0 & 0 & 6 & 0 \\
\hline 0 & 0 & 1 & 1 & 1 & 0 & 0 & 0 & 2 & 0 \\
\hline 1 & 1 & 0 & 0 & 0 & 0 & 0 & 0 & 1 & 0 \\
\hline 0 & 0 & 1 & 1 & 0 & 0 & 0 & 0 & 1 & 0 \\
\hline
\end{tabular}


In the process of analyzing with fsQCA, a complex solution consisting of different conditional variables is derived. According to the fact table A, the following analysis results are obtained: These four comprehensive results are the optimal combination of conditional variables, which represent the strongest explanatory power for the results, and the coverage of all combinations is 0.917 (see Table 7).

Table 7

Condition Combination Analysis Results (Truth Table A)

\begin{tabular}{|c|c|c|c|}
\hline Condition combination & Raw coverage & Unique coverage & Consistency \\
\hline $\begin{array}{l}\text { The introduction of new services or projects * extend the existing services to } \\
\text { new customers * produce some new products * organize new activities for } \\
\text { customers, employees, or volunteers * redesign existing products * } \\
\text { significant changes in the delivery of existing services * the introduction of } \\
\text { new service delivery }\end{array}$ & 0.583 & 0.250 & 1.000 \\
\hline $\begin{array}{l}\text { Significant changes in existing services or projects * extend the existing } \\
\text { services to new customers * produce some new products * organize new } \\
\text { activities for customers, employees, or volunteers * redesign existing } \\
\text { products * significant changes in the delivery of existing services * the } \\
\text { introduction of new service delivery }\end{array}$ & 0.417 & 0.083 & 1.000 \\
\hline $\begin{array}{l}\sim \text { the introduction of new services or projects } * \sim \text { significant changes in } \\
\text { existing services or projects } * \sim \text { extend the existing services to new customers } \\
* \sim \text { produce some new products } * \text { organize new activities for customers, } \\
\text { employees, or volunteers } * \sim \text { significant changes in the delivery of existing } \\
\text { services } * \text { the introduction of new service delivery }\end{array}$ & 0.167 & 0.167 & 1.000 \\
\hline $\begin{array}{l}\sim \text { the introduction of new services or projects } * \text { significant changes in } \\
\text { existing services or projects } * \sim \text { extend the existing services to new customers } \\
* \sim \text { produce some new products } * \text { organize new activities for customers, } \\
\text { employees, or volunteers } * \text { redesign existing products } * \sim \text { significant changes } \\
\text { in the delivery of existing services } * \text { the introduction of new service delivery }\end{array}$ & 0.083 & 0.083 & 1.000 \\
\hline
\end{tabular}

Solution coverage

0.917

Note. "*" means "and", "+" represents "or", "-" indicates the condition variables instead of the original variable value, and its logical formula is: $\sim \mathrm{C}=1-\mathrm{C}$ (C represents a condition variable).

The paper selects "provide new training topics for employees or volunteers", "adopt a new organizational structure", "implement new recruitment of staff and volunteer", "implement new incentives of employee and volunteer", and "implement new performance evaluation system" as five explained variables to explain the outcome variable and establishes truth table B of management innovation in nonprofit organizations, as shown in Table 8.

Table 8

Truth Table B

\begin{tabular}{|c|c|c|c|c|c|c|}
\hline $\begin{array}{l}\text { Provide new } \\
\text { training topics for } \\
\text { employees or } \\
\text { volunteers }\end{array}$ & $\begin{array}{l}\text { Adopt a new } \\
\text { organizational } \\
\text { structure }\end{array}$ & $\begin{array}{l}\text { Implement new } \\
\text { recruitment of staff } \\
\text { and volunteer }\end{array}$ & $\begin{array}{l}\text { Implement new } \\
\text { incentives of } \\
\text { employee and } \\
\text { volunteer }\end{array}$ & $\begin{array}{l}\text { Implement new } \\
\text { performance } \\
\text { evaluation system }\end{array}$ & Case & $\begin{array}{l}\text { Organizational } \\
\text { performance }\end{array}$ \\
\hline 1 & 1 & 1 & 1 & 1 & 9 & 1 \\
\hline 1 & 0 & 1 & 0 & 0 & 1 & 1 \\
\hline
\end{tabular}


(Table 8 continued)

\begin{tabular}{|c|c|c|c|c|c|c|}
\hline $\begin{array}{l}\text { Provide new } \\
\text { training topics for } \\
\text { employees or } \\
\text { volunteers } \\
\end{array}$ & $\begin{array}{l}\text { Adopt a new } \\
\text { organizational } \\
\text { structure }\end{array}$ & $\begin{array}{l}\text { Implement new } \\
\text { recruitment of staff } \\
\text { and volunteer }\end{array}$ & $\begin{array}{l}\text { Implement new } \\
\text { incentives of } \\
\text { employee and } \\
\text { volunteer }\end{array}$ & $\begin{array}{l}\text { Implement new } \\
\text { performance } \\
\text { evaluation system }\end{array}$ & Case & $\begin{array}{l}\text { Organizational } \\
\text { performance }\end{array}$ \\
\hline 1 & 0 & 0 & 0 & 0 & 2 & 0 \\
\hline 1 & 0 & 0 & 1 & 0 & 3 & 0 \\
\hline 0 & 0 & 0 & 0 & 0 & 5 & 0 \\
\hline 1 & 1 & 1 & 0 & 0 & 1 & 0 \\
\hline 0 & 0 & 0 & 1 & 0 & 1 & 0 \\
\hline 1 & 0 & 1 & 1 & 0 & 1 & 0 \\
\hline
\end{tabular}

In the process of analyzing with fsQCA, a complex solution consisting of different conditional variables is derived. According to the fact table B, the following analysis results are obtained: These two comprehensive results are the optimal combination of conditional variables, which represent the strongest explanatory power for the results, and the coverage of all combinations is 0.833 (see Table 9).

Table 9

Condition Combination Analysis Results (Truth Table B)

\begin{tabular}{|c|c|c|c|}
\hline Condition combination & Raw coverage & Unique coverage & Consistency \\
\hline $\begin{array}{l}\text { Provide new training topics for employees or volunteers * } \\
\text { adopt a new organizational structure * implement new } \\
\text { recruitment of staff and volunteer * implement new } \\
\text { incentives of employee and volunteer * implement new } \\
\text { performance evaluation system }\end{array}$ & 0.833 & 0.833 & 1.000 \\
\hline $\begin{array}{l}\text { Provide new training topics for employees or volunteers } * \sim \\
\text { adopt a new organizational structure } * \text { implement new } \\
\text { recruitment of staff and volunteer } * \sim \text { implement new } \\
\text { incentives of employee and volunteer } * \sim \text { implement new } \\
\text { performance evaluation system }\end{array}$ & 0.75 & 0.75 & 1.000 \\
\hline Solution coverage & 0.833 & & \\
\hline
\end{tabular}

Note. "*” means "and", "+" represents "or", "-" indicates the condition variables instead of the original variable value, and its logical formula is: $\sim \mathrm{C}=1-\mathrm{C}$ (C represents a condition variable).

\section{Based on the Analysis of Regression}

After the analysis of the results, the authors use the regression analysis to test again. The condition variable combination of qualitative comparison analysis results can be supported in the regression analysis. The results are as follows (see Table 10). 
Table 10

Multivariate Regression Analysis Results

\begin{tabular}{|c|c|c|c|c|}
\hline \multirow{2}{*}{ The variable name } & \multirow{2}{*}{$\begin{array}{l}\text { The standard } \\
\text { regression } \\
\text { coefficient (Beta) }\end{array}$} & \multirow{2}{*}{$\begin{array}{l}\text { Significance } \\
\text { level }^{1} \text { (Sig.) }\end{array}$} & \multicolumn{2}{|c|}{$95 \%$ confidence interval } \\
\hline & & & Lower bound & Upper bound \\
\hline The introduction of new services or projects & 0.061 & 0.049 & 0.000 & 0.095 \\
\hline Significant changes in existing services or projects & 0.153 & 0.001 & 0.047 & 0.179 \\
\hline Extend the existing services to new customers & 0.031 & 0.389 & -0.027 & 0.070 \\
\hline Produce some new products & 0.017 & 0.744 & -0.072 & 0.100 \\
\hline Organize new activities for customers, employees, or volunteers & 0.131 & 0.019 & 0.018 & 0.196 \\
\hline Redesign existing products & 0.084 & 0.098 & -0.012 & 0.144 \\
\hline Significant changes in the delivery of existing services & 0.033 & 0.526 & -0.053 & 0.104 \\
\hline The introduction of new service delivery & 0.120 & 0.020 & 0.015 & 0.169 \\
\hline Provide new training topics for employees or volunteers & 0.106 & 0.033 & 0.008 & 0.181 \\
\hline Adopt a new organizational structure & 0.132 & 0.018 & 0.016 & 0.178 \\
\hline Implement new recruitment of staff and volunteer & 0.151 & 0.003 & 0.043 & 0.207 \\
\hline Implement new incentives of employee and volunteer & -0.009 & 0.774 & -0.021 & 0.015 \\
\hline Implement new performance evaluation system & 0.063 & 0.215 & -0.028 & 0.124 \\
\hline
\end{tabular}

Note. Dependent variable: organizational performance.

According to the data presented in Table 10, the significance level of Sig value is greater than 0.05 in the six independent variables, which is not significant ${ }^{2}$, including "extend the existing services to new customers", "produce some new products", "redesign existing products", "significant changes in the delivery of existing services", "implement new incentives of employee and volunteer", and "implement new performance evaluation system". While the other seven independent variables of significance level are less than 0.05 , the results are reliable. Through the test of significance level in seven independent variables, the standard regression coefficient of "significant changes in existing services or projects" is 0.153 , which proves that "significant changes in existing services or projects" has positive effect on the result of performance of nonprofit organizations. After the regression analysis, these seven independent variables of standard regression coefficient are effective, including "the introduction of new services or projects", "significant changes in existing services or projects", "organize new activities for customers, employees, or volunteers", "the

\footnotetext{
${ }^{1}$ In regression analysis, the higher the significance is, the greater the reliability of the analysis results are. Sig value is less than 0.01 , indicating that the analysis results have significant significance; Sig value is less than 0.05 , indicating that the analysis results are significant; Sig value is greater than 0.05 , indicating that the analysis results are not significant.

2 The conditional variables and the outcome variables in the QCA analysis are called as autoregressive and dependent variables in the regression analysis. The names are strictly different, although the meaning is essentially the same.
} 
introduction of new service delivery", "provide new training topics for employees or volunteers", "adopt a new organizational structure", and "implement new recruitment of staff and volunteer". In addition, in order to further determine the reliability of the test results, the authors added $95 \%$ confidence coefficient test. The confidence intervals of the seven independent variables are not included in 0 , then after the regression analysis, it is concluded that the standard regression coefficient is effective.

\section{Lessons Learned}

Through the qualitative comparison analysis, it is concluded that the optimal combination of condition variables of technology innovation in nonprofit organizations is in the form of: the introduction of new services or projects * extend the existing services to new customers * produce some new products * organize new activities for customers, employees, or volunteers * redesign existing products $*$ significant changes in the delivery of existing services * the introduction of new service delivery. Meanwhile, it is concluded that the optimal combination of condition variables of management innovation in nonprofit organizations is in the form of: provide new training topics for employees or volunteers * adopt a new organizational structure * implement new recruitment of staff and volunteer * implement new incentives of employee and volunteer * implement new performance evaluation system.

Based on the regression analysis of the 23 cases of nonprofit organizations, the authors found that seven independent variables have causal relationship with organizational performance, including "the introduction of new services or projects", "significant changes in existing services or projects", "organize new activities for customers, employees, or volunteers", "the introduction of new service delivery", "provide new training topics for employees or volunteers", "adopt a new organizational structure", and "implement new recruitment of staff and volunteer".

The results of regression analysis support the optimal combination of condition variables of technology innovation in nonprofit organizations in the form of: the introduction of new services or projects * organize new activities for customers, employees, or volunteers * the introduction of new service delivery. The results of regression analysis support the optimal combination of condition variables of management innovation in nonprofit organizations in the form of: provide new training topics for employees or volunteers * adopt a new organizational structure * implement new recruitment of staff and volunteer.

So this paper concluded the performance in nonprofit organizations for a collection of logic: the optimal performance in nonprofit organizations $=$ the introduction of new services or projects * organize new activities for customers, employees, or volunteers * the introduction of new service delivery + provide new training topics for employees or volunteers * adopt a new organizational structure * implement new recruitment of staff and volunteer.

\section{Conclusions}

Taking 23 tertiary hospitals in Beijing as an example, this paper found the influence of organizational innovation on the performance of nonprofit organizations. Through the qualitative comparative analysis and regression analysis, the authors have found that "technology innovation" and "management innovation" have an important role. As a result, the six factors are key factors of nonprofit organizations, which play a key role on performance in nonprofit organizations, including "the introduction of new services or projects", "organize new activities for customers, employees, or volunteers", "the introduction of new service delivery", "provide 
new training topics for employees or volunteers", "adopt a new organizational structure", and "implement new recruitment of staff and volunteer". Other factors also affect the performance in nonprofit organizations. The optimal performance in nonprofit organizations for a collection of logic is: the introduction of new services or projects * organize new activities for customers, employees, or volunteers * the introduction of new service delivery + provide new training topics for employees or volunteers $*$ adopt a new organizational structure * implement new recruitment of staff and volunteer. Through regression analysis of the second inspection, some of the variables of QCA were excluded, but the effect of the excluded variables on performance in nonprofit organizations existed. This suggested that some of the excluded variables had an effect on performance in nonprofit organizations. In the future, the authors will explore how these excluded variables influence the performance in nonprofit organizations.

\section{References}

Backes-Gellner, U., Kluike, M., Pull, K., Schneider, M. R., \& Teuber, S. (2016). Human resource management and radical innovation: A fuzzy-set QCA of US multinationals in Germany, Switzerland, and the UK. Journal of Business Economics, 86(7), 751-773.

Bai, J., \& Zhang, S. (2005). Systematic thinking of enterprise organizational innovation. Economic Aspect, 1162-1164.

Blau, J. R., \& McKinley, W. (1979). Ideas, complexity, and innovation. Administrative Science Quarterly, 24(2), $200-219$.

Carmen, C., \& María José, G. (2008). The role of technological and organizational innovation in the relation between market orientation and performance in cultural organizations. European Journal of Innovation Management, 11(3), 413-434.

Chen, Y., He, L., \& Si, C. (2007). A study on relationship between open innovative culture, market driven and innovative performance of high-technology enterprise-Empirical study on Jiang/Zhe/Hu/Min regions. Studies in Science of Science, 25(3), 567-572.

Damanpour, F., \& Evan, W. M. (1984). Organizational innovation and performance: The problem of organizational lag. Administrative Science Quarterly, 29(3), 392-409.

Dy Sydney, M., Garg, P., \& Nyberg, D. (2005). Critical pathway effectiveness: Assessing the impact of patient, hospital care, and pathway characteristics using qualitative comparative analysis. Health Services Research, 40(2), 499-516.

Faridah, D., \& Faïz, G. (2001). Patterns of innovation organization in service firms: Postal survey results and theoretical models. Science and Public Policy, 28(1), 57-67.

Gatignon, H., Tushman, M. L., \& Smith, W. A. (2002). A structural approach to assessing innovation: Construct development of innovation locus, type and characteristics. Management Science, 48(9), 1103-1122.

Harris, M. (1989). The governing body role: Problems and perceptions in implementation. Nonprofit and Voluntary Sector Quarterly, 24(2), 156-167.

Hull, C., \& Lio, B. (2006). Innovation in non-profit and for-profit organizations: Visionary, strategic, and financial considerations. Journal of Change Management, 6(1), 53-65.

Jaskyte, K., \& Dressler, W. W. (2005). Organizational culture and innovation in non-profit human service organizations. Administration in Social Work, 29(2), 23-41.

Kane, H., \& Hinnant, L. D. (2017). Pathways to program success: A qualitative comparative analysis (QCA) of communities putting prevention to work case study programs. Journal of Public Health Management and Practice, 23(2), $104-111$.

Kimberly, J. R. (1981). Managerial innovation. New York: Oxford University Press.

Lumpkin, G. T., \& Dess, G. G. (1996). Clarifying the entrepreneurial orientation construct and linking it to performance. Academy of Management Review, 21(1), 135-172.

Perri. (1993). Innovation by nonprofit organizations: Policy and research issues. Nonprofit Management and Leadership, 3(4), 397-414.

Schin, J., \& McClomb, G. E. (1998). Top executive leadership and organizational innovation: An investigation of nonprofit human service organizations. Administration in Social Work, 22(3), 1-21.

Schumpeter, J. A. (1934). Theory of economic development. Cambridge: Harvard University.

Scott, S. G., \& Bruce, R. A. (1994). Determinants of innovative behavior: A path model of individual innovation in the workplace. Academy of Management Journal, 37(3), 580-607. 
Tidd, J., \& Hull, F. M. (2003). Service innovation: Organizational responses to technological opportunities and market imperatives. London: World Scientific.

Wang, M. (2007). China's NGO development status and policy analysis. Public Administration Review, 6(1), 132-150.

West, M., \& Farr, J. (1990). Innovation and creativity at work: Psychological and organizational strategies. Chichester: Wiley.

Yoo, D. K., \& Park, J. A. (2007). Perceived service quality: Analyzing relationships among employees, customers, and financial performance. International Journal of Quality and Reliability Management, 24(9), 908-926.

Zaltman, G., Duncan, R., \& Holbek, J. (1973). Innovations and organizations. New York: Wiley. 